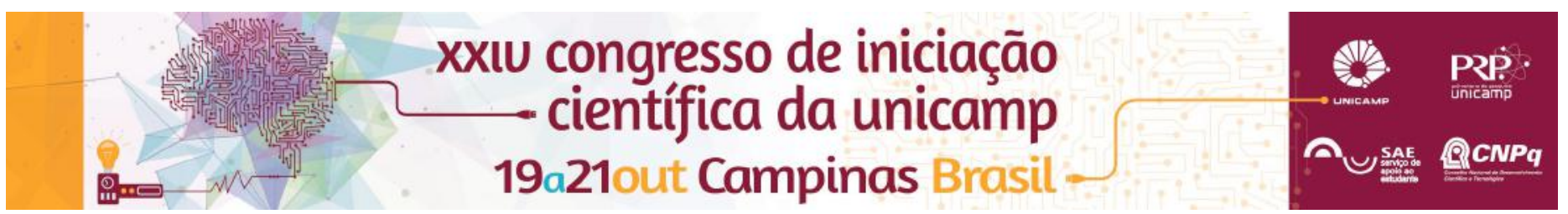

\title{
Análise de imagem urbana do bairro Vila Industrial, Campinas; relacionando a história urbanística com a percepção atual.
}

\section{Luna Viana A. de Oliveira*}

\section{Resumo}

Um lugar não deve-se considerá-lo sendo simplesmente um sítio, mais sim resultado de percepções, vivências, e memórias diferentes. A cidade cresce sobre si mesma, sendo construída através do tempo, através de sobreposições de décadas. Tendo isso em vista, busca-se estudar o bairro Vila Industrial, localizado em Campinas-SP, curioso por todas suas particularidades, características e riqueza histórica. Para realizar o estudo, será relacionada a história urbanística do bairro, e suas modificações, com a percepção atual de que as pessoas têm dele. Assim, se compreenderá como o bairro foi se configurando como imagem através do tempo e como essas transformações históricas afetam na percepção que se tem dele hoje.

\section{Palavras-chave:}

Imagem urbana, percepção urbana, lares e penates.

\section{Introdução}

Segundo Lynch¹, a imagem urbana de um ambiente é um processo bilateral entre o observador e seu ambiente. Acompanhando esse pensamento, Aldo Rossi $^{2}$ acredita que a cidade cresce sobre si mesma; é construída ao decorrer do tempo e sua forma se sobrepõe sobre ela mesma, podendo ser alterada; mas a imagem que cada um tem dela pode permanecer intacta na memória ou ser modificada dependendo de sua vivencia e percepção. Ao se estudar um lugar, não se deve considera-lo sendo apenas um sítio. Ele contém significado e é constituído a partir das práticas, usos, forma, populaçãoo, sentidos, experiência. O bairro é justamente o centro das experiências urbanas, de seus habitantes, populaçãoo transitória, história e atualidade, e é sobre ele que esta pesquisa se desenvolve.

\section{Resultados e Discussão}

A pesquisa se desenvolveu baseada no método de Kevin Lynch de estudo das cidades, buscando através de uma série de diferentes olhares, percepções e análises uma forma de compreendê-las. Ao invés de aplicá-lo para toda a cidade de Campinas, concentrou-se apenas no bairro da Vila Industrial, objeto de pesquisa. Além do método tradicional de Lynch, foram incorporados a pesquisa mais dois tipos de análises para melhor leitura do local: um intenso levantamento histórico e entrevistas não só com moradores antigos do bairro, mas também com moradores jovens/recentes e com os que usufruem dos recursos do bairro mas não são moradores. Marandola Jr. (2001) nomeia esses dois tipos de cidadãos em lares e penates, em alusão ao livro de Ítalo Calvino.

Muitas vezes, a percepção que se obtém do lugar e de elementos urbanos ao percorrê-lo e ao coletar informações de artigos e jornais, ou seja, aquela que se parecia óbvia para a composição da imagem do bairro, nem todas são relevantes para os próprios habitantes, tanto de lares como penates. A imagem de um lugar está diretamente ligada a sua memória afetiva e perceptiva dos meios que mais são ou foram presentes no seu dia-a-dia. Também é difícil desvincular a imagem que o bairro tinha antes e atualmente. Ambas as épocas ajudam a formar sua imagem.

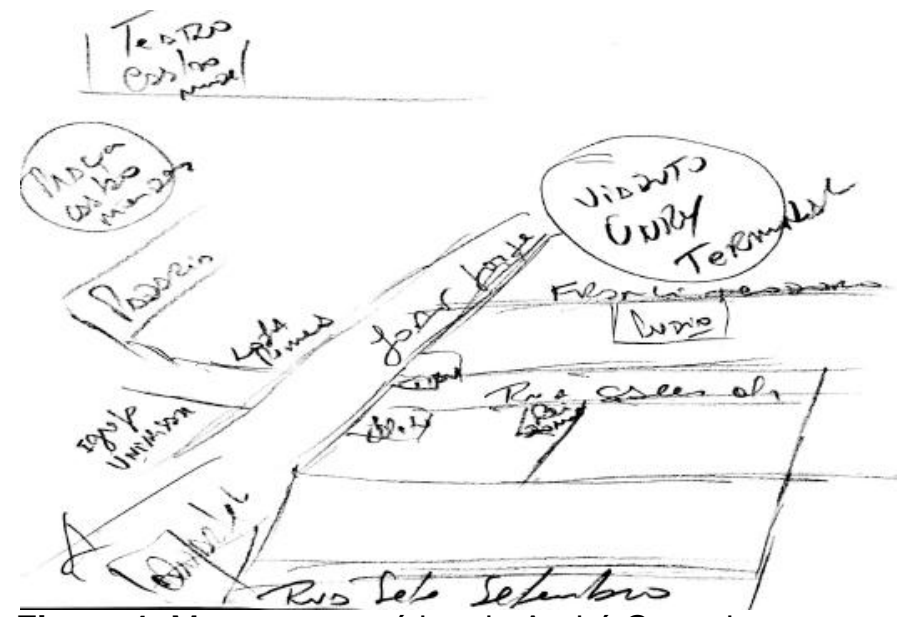

Figura 1. Mapa esquemático de André Gonçalves

\section{Conclusões}

Compreender a história da Vila Industrial foi muito importante para entender sua imagem, pois independente do tempo que a pessoa frequenta ou mora no bairro, ela sempre vai remeter algo a sua história, identificar elementos e discorrer sobre eles. Os lugares e regiões mais marcantes para os entrevistados foram justamente onde eles conviviam, vivem ou trabalham. Isso mostra que o que realmente forma a imagem de um lugar é sua vivência, práticas, usos e experiências nele. A imagem da Vila Industrial para cada pessoa resulta em uma composição de forma e estrutura aplicadas de maneiras diferentes, podendo uma mesma situação ser interpretada de maneira rígida ou totalmente flexível.

\section{Agradecimentos}

Agradeço primeiramente a PIBIC, que possibilitou a execução desta pesquisa; ao meu orientador Evandro Ziggiatti que sempre demonstrou interesse pelo projeto; e sobretudo aos entrevistados, em especial ao André, que nostalgicamente me fez lembrar da minha infância e dos bons momentos.

${ }^{1}$ LYNCH, Kevin. A imagem da cidade. 1. ed. São Paulo: Martins Fontes, $2^{\mathrm{a}}$ tiragem, 1999.

2 ROSSI, Aldo. A arquitetura da cidade. 2. ed. São Paulo: Martins Fontes, 2001. 